\title{
A REVISION OF THE PLIOCENE NON-MARINE MOLLUSCA OF ENGLAND.
}

\author{
By A. S. Kennard \& B. B. Woodward, F.L.S., etc.
}

Read 11 th November, 1898.

Although the non-marine mollusca of the pliocene deposits of this country have received considerable attention, the state of our knowledge concerning them is nevertheless not very satisfactory. Much of our information is out of date, whilst the whole of it is so scattered through various journals that it entails a large amount of research to find the different records. Hence it has appeared desirable to collect all the data available, and by checking the various identifications, as far as possible, from the specimens themselves, to establish the record on a more satisfactory basis. The pliocene non-marine molluscan fauna is of great interest both to the geologist, endeavouring to restore a true picture of pliocene times, and to the malacologist, struggling with problems of distribution, because it is in the Red and Norwich Crags that the genesis of our present molluscan fauna is to be sought. It is a noteworthy fact that many of our existing species are met with for the first time in these beds, and are not known to have existed on the continent till a much later date. This may result from the imperfection of the geological record, or it may indicate that these forms have been derived from a region to the northward, and it is worthy of remark, as giving additional weight to this latter hypothesis, that there are forms in North America closely allied to the species under consideration. Some of the operculate aquatic forms also occur in the Congeria Beds, and are therefore presumably members of the old Aralo-Caspian fauna; whilst a few of the species are as yet totally unknown in the fossil state on the continent.

The finest series of pliocene non-marine mollusca is undoubtedly that comprised in the Searles V. Wood Collection now at the British Museum (Natural History); whilst there is a fair series in the general collection there, in addition to the unique specimens from Walton and Hollesley, formerly belonging to the late $\mathrm{Mr}$. Robert Bell, that are now being arranged for public exhibition. The Canham Collection, preserved in the Ipswich Museum, also contains several interesting examples, whilst Mr. Reeve's specimens are in the Norwich Museum.

Before proceeding further, we would like to take this opportunity of returning our sincerest thanks to those gentlemen who so kindly permitted us to examine the specimens under their charge, or in their possession, as well as to those who have so freely rendered assistance in other ways in the compilation of this paper. We refer more particularly to Dr. Henry Woodward, Mr. R. Bullen Newton, and Mr. E. A. Smith, of the British Museum (Natural History); Mr. E. T. Newton and Mr. H. A. Allen, of the Museum of Practical Geology ; Mr. James Reeve, of the Norwich Castle Museum; Mr. Woolnough, of the Ipswich Museum; Mr. H. W. Burrows, Mr. E. R. Sykes, and Mr. Clement Reid.

VOL. III.-MARCH, 1899. 
It may be as well to state that we have accepted the view that the Weybourn Crag and Forest Bed series are not pliocene, but pleistocene. This opinion is almost universally held on the continent, but it has not been widely adopted in this country, although the evidence is, we venture to think, all in favour of this conclusion.

In the determination of the species allowance has been made for variation in the past, and in this way unnecessary additions, as we deem them, to already overburdened lists are avoided. In those cases where it has been impossible to trace the specimens, and there is no inherent improbability of the correctness of their identification, the species are cited on the authority of their recorder.

Doubts have been expressed as to the true pliocene age of the land-shells from Butley, but these doubts, we consider, have no foundation; and it may here be mentioned that during a visit to the Neutral Farm pit by one of us last June, three examples of Limnaa truncatula and one of Planorbis marginatus were obtained, whilst more recently Mr. H. W. Burrows has also obtained these same species at that spot, and $\mathrm{Mr}$. R. Holland has been fortunate enough to find a good example of Hygromia hispida. The records of foreign occurrences are mainly on the authority of the late Dr. C. L. F. Sandberger ("Die Land- und Süsswasser Conchylien der Vorwelt"), and are confined to those citations under the names employed in this paper.

The first notice of the occurrence of non-marine mollusca in the pliocene deposits of this country was by Samuel Woodward, the Norfolk geologist, who in 1833 figured four species from the Norwich Crag (1). In 1839 Sir Charles Lyell listed twenty-one species, on the authority of S. V. Wood, G. B. Sowerby and himself (2), these also being all from the Norwich Crag, with the note that one form, Planorbis marginatus, likewise occurred in the Red Crag. Mr. S. V. Wood in 1842 enumerated eleven species, of which two were from the Red Crag (3). The first part of that author's Monograph of the Crag Mollusca, containing the Gastropoda, was published in 1848, and seventeen species were there given (4). The volume containing the Pelecypoda was issued in three parts - the first appearing in 1851, the second in 1853 , and the third in $1857(5)$. Three additional species were listed, thus raising the total to twenty. Nineteen species from the Norwich Crag alone were next recorded by S. P. Woodward (6) in 1864. In $1869 \mathrm{Mr}$. Alfred Bell enumerated four species from the Red Crag of Butley (7), and in 1870 he added another, Hygromia hispida (8). In the following year he noted Limnaa palustris as also occurring there (9), and also recorded two forms from Waldringfield and one from Walton (10). In 1871, too, appeared the important papers by the late Sir Joseph Prestwich, and lists of the non-marine species from the Red and the Norwich Crags, on the authority of Gwyn Jeffreys, were given, the former containing nine and the latter twenty-one species, eight being common to both (11). In 1872 Alfred \& Robert Bell published the result of their researches, giving a list of thirty species (12). The same year saw the issue of the first part of the supplement to Wood's Monograph of the Crag Mollusca, the completion not being published till 1874, 
and in this nine species were enumerated which had not previously been recorded by him (13). In 1879 appeared the list of fossils from Bramerton by Mr. J. Reeve, embodying the result of many years' work at the sections there (14), and an additional list was published by him in 1881 (17), and in these lists twenty-two species were given. A few species were also recorded in 1879 from a well-section at Beccles by Mr. W. M. Crowfoot (15). S. V. Wood, also in 1879, published the second supplement to his monograph, adding six species to his previous lists (16). In 1884 Robert Bell recorded eleven species of land-shells from the Red Crag, and noted the occurrence of three species at Walton (18); and finally, in 1890, Mr. Clement Reid was able from the above sources to compile a list of thirty-nine species (19).

\section{BibliogRAPHY.}

1. 1833.-Woodward, S., "An Outline of the Geology of Norfolk."

2. 1839.-Lyell, Sir C., "On the relative Ages of the Tertiary Deposits commonly called 'Crag' in the Counties of Norfolk and Suffolk": Mag. Nat. Hist., ser. II, vol. iii, p. 313.

3. 1842.-Wood, S. V., "A Catalogue of Shells from the Crag" : Ann. \& Mag. Nat. Hist., vol. ix, pp. 455-462 \& 527-544.

4. 1848.-Wood, S. V., "The Crag Mollusca," Part I, Univalves. (Palæont. Soc.)

5. 1851-7.-Wood, S. V., "A Monograph of the Crag Mollusca," Part II, Bivalves. (Palæont. Soc.)

6. 1864.-Woodward, S. P., "Shells of the Newer Pliocene, or Norwich Crag": reprinted from "White's History and Directory of the County of Norfolk."

7. 1869.-Bell, A., "Suffolk and Sussex Tertiaries" : Geol. Mag., vol. vi, p. 41.

8. 1870.-BeLl, A., "On some new or little known Shells of the Crag Formation" : Ann. \& Mag. Nat. Hist., ser. Iv, vol. vi, p. 213.

9. 1871.-Bell, A., "The Butley Crag Pits" : Geol. Mag., vol. viii, pp. 452-3.

10. 1871.-Bell, A., "Contributions to the Crag Fauna": Ann. \& Mag. Nat. Hist., ser. Iv, vol. vii, p. 351.

11. 1871.-Prestwich, $\mathrm{S}_{\text {Ir }}$ J., "On the Structure of the Crag Beds of Suffolk and Norfolk," Part II, The Red Crag: Quart. Journ. Geol. Soc., vol. xxvii, p. 493. Part III, The Norwich Crag and Westleton Beds: t.c., p. 493.

12. 1872.-Bell, A. \& R., "On the English Crags": Proc. Geol. Assoc., vol. ii, p. 185.

13. 1872-4.-Wood, S. V., "Supplement to the Crag Mollusca," Part I, Univalves; Part II, Bivalves. (Palæont. Soc.)

14. 1879.-Reeve, J., "List of Fossils from the Norwich Crag at Bramerton": Proc. Norwich Geol. Soc., vol. i, pp. 69-72. 
15. 1879.-Crowfoot, W. M., "On the Well-Sections at Beccles": t.c., pp. $76-79$.

16. 1879.-Wood, S. V., "Second Supplement to the Monograph of the Crag Mollusca." (Palæont. Soc.)

17. 1881.-Reeve, J., "Additional List, etc.": Proc. Norwich Geol. Soc., vol. i, p. 110.

18. 1884.-Beld, R., "Land-Shells in the Red Crag": Geol. Mag., vol. i, p. 262.

19. 1890.- Rerd, C., "The Pliocene Deposits of Britain," pp. 228-230. (Mem. Geol. Surv.)

\section{Sphyradium edentulum (Drap.).}

Vertigo edentula, Drap. : S. V. Wood, Crag Moll., Suppt. II, p. 37, pl. iv, fig. 6 .

Form. and Loc.- Norwich Crag: Bramerton Common (Norwich Mus.); Blake's Pit, Bramerton (Norwich Mus.).

The only known examples of this species were found by Mr. Reeve. The typical form is as yet unknown from any pre-holocene beds of the continent, though the variety, considered there a good species and known as Vertigo columella, Mts., is found in the lower pleistocene of Mosbach and in more recent beds. In this country both the type and the variety are found in pleistocene deposits.

\section{Pyramidula rysa (S. V. Wood).}

Helix rysa, S. V. Wood: Crag Moll., vol. i, p. 4, pl. i, fig. 1.

Helix rufescens, Penn., var.?: J. Gwyn Jettreys, Quart. Journ. Geol. Soc., vol. xxvii (1871), p. 493.

Patula (Janulus) rysa, S. V. Wood: C. L. F. Sandberger, Land- \& Sussw. Conch. Vorwelt, p. 737.

Form. and Loc.-Red Crag: Walton (Saffron Walden Mus. type); Waldringfield (Ipswich Mus.).

The type of this species was found by Mr. G. S. Gibson inside the mouth of an example of Chrysodomus antiquus, Linn., from Walton; whilst a second example was obtained by Mr. Canham from the coprolite diggers at Waldringfield. No other examples have been met with.

\section{Pyramidula Suttonensis (S. V. Wood).}

Helix Sutionensis, S. V. Wood : Crag Moll., Suppt. I, p. 2, pl. i, fig. 2.

Form. and Loc.-Coralline Crag: Sutton (S. V. Wood Coll., British Museum).

The single example of this form found by Wood still remains unique. It is said by him to greatly resemble Pyramidula calathus (Lowe) and P. bifrons (Lowe) from Madeira, and a recent comparison 
fully bears out this view. Helix Suttonensis can therefore be referred, with the preceding, to Lowe's section Janulus.

\section{Eulota fruticum (Müll.).}

Form. and Loc.-Red Crag: Hollesley.

The only known example of this species, now in the British Museum (Natural History), was formerly in the collection of the late Robert Bell. On the tablet to which it is affixed is the following note in his handwriting: "This shell was taken out of a pit near the road occupied as a barnyard, Page's Farm. It was in company with marine shells and Limnaa, and Planorbis was found with it. 1885." Although now extinct in Britain, it has been found in the pleistocene at Barnwell, Stutton, ${ }^{1}$ and Ilford. Across the Channel it has been recorded from the lower pleistocene of Mosbach, and the middle pleistocene of Cannstadt, and Nussdorf, near Vienna.

\section{Hygromia incarnata (Müll.).}

Form. and Loc.-Red Crag: Walton.

The only known example of this species was found in 1882 by the late Mr. Groom (alias Groom-Napier, the soi-disant 'Prince of Mantua') at Walton, and is now in the British Museum (Natural History). (See Geol. Mag., 1884, p. 264.) It is not a perfect example, but no doubt can be entertained of this determination. On the continent the species has only been found in the middle pleistocene of Cannstadt, Würtemberg.

\section{Hrgromia HISPIDA (Linn.).}

Helix hispida, Linn.: S. V. Wood, Crag Moll., vol. i, p. 2, pl. i, figs. $3 a-c$.

Form. and Loc.-Red Crag: Butley. Norwich Crag: Bramerton Common and Blake's Pit, Bramerton; Thorpe, Norfolk; Horstead; Dunwich; Yarn Hill; Bulchamp ; Coltishall (Prestwich).

This is by far the commonest helicoid in our pliocene beds, though it should be noted that ail non-marine forms are rare. On the continent it is unrecorded from any bed older than the lower pleistocene of Mosbach, where it is not infrequent, and it is one of our commonest pleistocene fossils.

\section{Hygromia rubigrnosa (A. Schmidt). Fig. I.}

Form. and Loc.-Norwich Crag: Southwold.

In the S. V. Wood Collection at the British Museum (Natural History) is a Hygromia labelled "Helix sp." We have identified this

1 The single example figured and described from this locality by Mr. S. V. Wood (Crag Moll., vol. ii, p. 308, pl. xxxi, fig. 19) is now in the Searles Wood Collection at the Norwich Museum. 
specimen with examples of " $H$. rubiginosa, Zieg.," in the collection lately acquired by the Trustees of the British Museum from the Rev. R. Merle Norman. This species, as shown by A. Schmidt ${ }^{1}$ (who adopted Ziegler's manuscript name), is distinct from, though nearly allied to, that usually known on the continent as $H$. sericea, Drap. (H. sericea, Müll., which is proved to be the young of another species predates this name, but we are not concerned with the correct name of this latter species at present). This is not the Helix sericea, Drap., of Jeffreys (Brit. Conch.), which should be known as Hygromia gramulata, Alder. Hygromia rubiginosa has hitherto been unrecorded
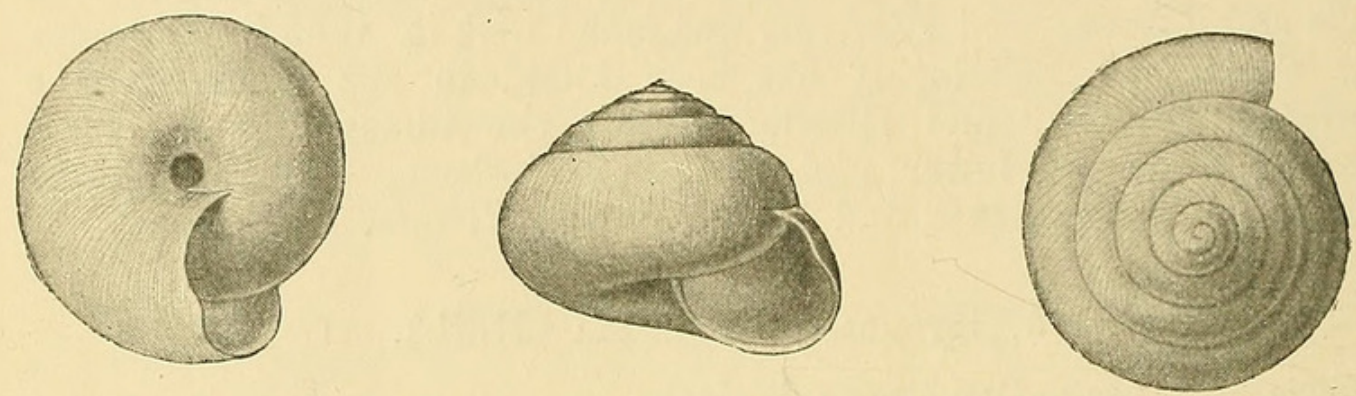

FIG. I. Hygromia rubiginosa (Schmidt). Norwich Crag: Southwold.

from this country, either fossil or recent. Tryon is undoubtedly in error in placing it as a variety of $H$. granulata, Alder. ${ }^{2}$ It has been recorded living from Scandinavia, North Germany, Jutland, Saxony, Bohemia, the Hartz, and the Carpathians.

\section{Vallonia pulchella (Müll.).}

Helix pulchella, Müll.: S. V. Wood, Crag Moll., vol. i, p. 3, pl. i, fig. 4.

Vallonia tenuilimbata, C. L. F. Sandberger, "Ein Beitrag zur Kenntniss der unterpleistocänen Schichten Englands": Palæontogr., 1880, p. 102, pl. xii, fig. 13.

Form. and Loc.-Red Crag?: Bawdsey (Brit. Mus.). Norwich Crag: Bramerton Common and Blake's Pit (Norwich Mus.); Beccles (W. M. Crowfoot).

The example from Bawdsey is stated by Mr. Wood to have been found in loose and disturbed Crag, so it is possible that that one may not be a true pliocene fossil ; but the examples from Bramerton are undoubted as to their age. We cannot agree with Sandberger in separating the Crag and the Forest Bed examples from the recent form.

Judging from the figures and description, Vallonia subpulchella, Sandb., ${ }^{3}$ from the middle miocene, near Steinham in Würtemberg, is

1. Zeitschrift für Naturw., 1853, vol. i, p. 3.

2 Manual of Conchology, ser. II, vol. iii, p. 178.

3 C. L. F. Sandberger, "Die Land- und Süsswasser Conchylien der Vorwelt," p. 544 . 
identical with this species. $V$. pulchella occurred in a boring at Amsterdam at a depth of 229 metres, ${ }^{1}$ thus proving its existence on the continent in pliocene times, for the next earliest record is from the lower pleistocene of Mosbach.

\section{Helicodonta lens (Fér.).}

Form. and Loc.-Red Crag: Walton.

An example of this species is stated by Robert Bell ${ }^{2}$ to have been found at Walton about 1881 by Mr. Larcher, of King's College. The shell was identified by Dr. Gwyn Jeffreys and Mr. J. H. Ponsonby ; but we have been unable to trace the specimen. The species is not recorded in a fossil state on the continent.

\section{Helicigona arbustordm (Linn.).}

Helix arbustorum, Linn.: S. V. Wood, Crag Moll., vol. i, p. 3, pl. i, fig. 3.

Form. and Loc.-Red Crag: Butley (Ipswich Mus. and E. R. Sykes Coll.). Norwich Crag: Coltishall (Brit. Mus. and Mus. Pract. Geol.); Southwold (S. V. Wood); Postwick (Mus. Pract. Geol.).

All the examples seen differ somewhat from the normal form, but we have no doubt as to the determination. Its first recorded appearance on the continent is in the lower pleistocene of Mosbach; but in the middle and upper pleistocene it has been found at Lyons, Nussdorf near Vienna, Bruchsal in Baden, and numerous other localities.

\section{Helix lactea, Müll.}

Form. and Loc.-Red Crag: Walton (Brit. Mus.).

A fine example, nearly perfect, was found in 1883 at Walton by Robert Bell, who states ${ }^{3}$ that it "resembles an Algerian form more than any other." The fragment belonging to the same species which he says he also found we have been unable to trace. Helix lactea is unrecorded in a fossil state on the continent. According to Hanley ${ }^{4}$ the correct name for this species is Helix lucorum, Linn., but that question lying beyond the limits of this paper Müller's better known name is here employed.

\section{Cochlicopa lubrica (Müll.).}

Bulimus lubricus, Müll. : S. V. Wood, Crag Moll., Suppt. II, p. 38, pl. iv, fig. 10 .

Form. and Loc.-Red Crag: Butley (two examples, Ipswich Mus.).

1 Dr. J. Lorié, "Contrib. à la Géol. des Pays Bas" : Bull. Soc. Belge Géol., tom. iii (1889), p. 435.

2 R. Bell, "Land-Shells in the Red Crag" : Geol. Mag., 1884, p. 262.

3 Geol. Mag., 1884, p. 264.

4 . S. Hanley, "Ipsa Linnæa Conchylia," p. 378. 
Two specimens found by Mr. Canham are the only ones known of pliocene age, its earliest records on the continent being from the lower pleistocene of southern Germany at Mosbach and the middle pleistocene of Cannstadt, Weimar, and Mulhausen in Thuringia. It is a common English pleistocene fossil, and is, of course, extremely abundant at the present day.

\section{Pupa cylindracea (Da C.).}

Form. and Loc-Norwich Crag: Blake's Pit, Bramerton (Norwich Mus.); Yarn Hill (R. E. Leach).

The geological record of this species is indeed very incomplete. A single example was found by Dr. Frank Corner in the upper pleistocene of Ilford, and it was common at Copford, but the age of this latter deposit is uncertain. On the continent it is as yet unrecorded. We have only seen a single example from the pliocene, and this was found by Mr. J. Reeve.

\section{Pupa muscorum (Linn.).}

Pupa muscorum, Müll. : S. V. Wood, Crag Moll., Suppt. I, p. 3, pl. i, fig. 7.

Pupa marginata, Drap. : J. Gwyn Jeffreys, Quart. Journ. Geol. Soc., vol. xxvii (1871), p. 493.

Form. and Loc.-Red Crag: Butley (Brit. Mus. and Ipswich Mus.). Norwich Crag: Blake's Pit, Bramerton (Nurwich Mus.); Yarn Hill (R. E. Leach).

The example figured by S. V. Wood, which was found by Mr. A. Bell, is now in the British Museum (Natural History), and there is an immature specimen from the same locality in the Canham Collection at the Ipswich Museum. Specimens of undoubted pliocene age occurred in a boring at Amsterdam at a depth of 230 metres. $^{1}$ Elsewhere on the continent it is unknown in any bed of earlier age than the middle pleistocene, it having been found at Wiesbach, Cannstadt, and Wiesbaden.

\section{Clausilita pliocena, S. V. Wood.}

Clausitia pliocena, S. V. Wood : Crag Moll., Suppt. I, p. 188, addendum pl., fig. 22.

The single immature example now in the British Museum (Natural History), from which this species was described, still remains unique. It certainly cannot be referred to any living English form. Dr. J. Lorié has recorded ${ }^{2}$ two examples from a boring at Diermerbrug, Holland, at a depth between 230 and 234 metres, but not having seen the examples it is impossible to say if this determination be correct or not.

1 Dr. J. Lorié, "Contrib. à la Géol. des Pays Bas": Bull. Soc. Belge Géol., tom. iii (1889), p. 436.

2 Tom. cit., p. 435. 
16. Succinea elegans, Risso.

Succinea oblonga, Drap.: S. V. Wood, Crag. Moll., vol. i, p. 6, pl. i, fig. 6.

Form. and Loc. - Norwich Crag: Coltishall (Norwich Mus.); Bulchamp (Brit. Mus.).

This form, though so abundant in the pleistocene beds of this country, is very rare in the pliocene. It is another of those species for a knowledge of existence of which on the continent in pliocene times we are indebted to Dr. Lorié, who has noted it as occurring in the borings at Gorkum, Utrecht, Diermerbrug, and Amsterdam. Elsewhere its earliest recorded appearance is in the lower pleistocene of Mosbach.

17. Succinea putris (Linn.).

Succinea putris, Linn: S. V. Wood, Crag Moll., vol. i, p. 5, pl. i, fig. 5 .

Form. and Loc.-Red Crag: Butley (Ipswich Mus.). Norwich Crag: Bramerton Common and Blake's Pit, Bramerton (Norwich Mus.).

This is a rare form in the Crag, and is unrecorded from any continental pliocene beds, making its first appearance there in the lower pleistocene of Mosbach, while in the middle and upper pleistocene it has been found in many localities.

18. Succinea oblonga, Drap.

Form. and Loc.-Norwich Crag: Southwold; Bulchamp.

We have only seen one example of this species, and that an imperfect one, in the S. V. Wood Collection at the British Museum (Natural History). It differs somewhat from the typical form of S. oblonga, but we do not think sufficiently so to warrant its separation. Although extremely rare in this country at the present day, it was in pleistocene times a widely distributed and common form, both here and on the continent.

\section{Limnata auricularia (Linn.).}

Limnaa auricularia, Linn. : S. V. Wood, Crag Moll., Suppt. II, p. 36, pl. iv, fig. 3 .

Form. and Loc.-Norwich Crag : Bramerton Common (Norwich Museum).

The only known example of this species is an immature specimen, and may be referred to the "var. acuta, Jeff." This is apparently a rare form on the continent in a fossil state, since it is only recorded from the middle pleistocene near Potsdam.

20. Limnea pereger (Müll.).

Form. and Loc.-Red Crag: Butley (A. Bell). Norwich Crag: Bramerton Common; Southwold; Bulchamp.

It is quite hopeless to attempt to unravel the synonymy of the pliocene forms of Limnaa pereger, $L$. palustris, or $L$. truncatula, since 
it is impossible to trace all the specimens figured by Wood; but with the exception of a solitary example of $L$. auricularia, all the representatives of this genus that we have seen from the Crag are referable to these three polymorphic species, and consequently the identifications of L. Pingelii, Möll., L. Holböllii, Möll., and L. elodes, Say, seem unreliable. L. pereger is common on the continent in beds of pleistocene age, and it is also known from the upper pliocene of Castellarquato, near Piacenza, northern Italy.

\section{Limnea palustris (Müll.).}

Limnaea Pingelii?, Möll.: S. V. Wood, Crag. Moll., Suppt. I, p. 3, pl. iv, fig. 4.

Form. and Loc.-Red Crag: Butley. Norwich Crag: Coltishall; Bramerton Common; Blake's Pit, Bramerton; Yarn Hill; Bulchamp (Prestwich).

This well-known form was apparently as variable in pliocene as it is in recent times. It is first recorded on the continent from the lower pleistocene of Mosbach, and it has also been noted from the upper pleistocene of Vinograd, near Buczak in Ukraine, and Kilianstadten near Hanau, as well as numerous other localities in France, Germany, and Austria.

\section{Limnata truncatula (Müll.).}

Form. and Loc.-Red Crag: Butley. Norwich Crag: Bramerton Common ; Thorpe, Norfolk.

The species is by no means rare at Butley, but it is apparently very scarce in the Norwich Crag, since we have seen only three examples from that deposit. Wood states ${ }^{1}$ that he has never seen the true form of this species from any English pliocene deposit, and considers that the specimens so called should be referred to $L$. Holböllii, Möll.; but $L$. truncatula is an extremely variable form, and all the Crag variations can be matched with recent English examples. Its earliest recorded appearance on the continent is from the lower pleistocene of Mosbach. It is also known from the upper pleistocene of Oberissigheim near Hanau, of Russia and Algiers.

\section{Planorbis corneus (Linn.).}

Planorbis corneus, Linn. : S. V. Wood, Crag Moll., vol. i, p. 10, pl. i, fig. 12 .

Form. and Loc.-Norwich Crag: Southwold (Brit. Mus.); Bulchamp (S. V. Wood).

A single example, and that immature, is the only evidence of the existence of the present species in pliocene times in England that we have seen. This is yet another of those forms which are first recorded fossil on the continent from the lower pleistocene of Mosbach.

1 Crag Moll., Suppt. I, p. 3. 


\section{Planorbis marginatus, Drap.}

Planorbis complanatus, Linn.: S. V. Wood, Crag Moll., vol. i, p. 9, pl. i, fig. 10 .

Form. and Loc.-Red Crag: Butley. Norwich Crag: Norwich; Bramerton Common; Blake's Pit, Bramerton ; Southwold ; Bulchamp; Coltishall.

This species has been found in three pits at Butley, viz.: the Neutral Farm pit, commonly known as the Oyster pit, the pit near Butley Mill, and another on Butley Common. All the examples we have seen are immature. It has been recorded from the lower pliocene of France ${ }^{1}$ (Molasse d'eau douce du Lyonnais et du Dauphiné).

\section{Planorbis spirorbis (Linn.).}

Planorbis spirorbis, Linn.: S. V. Wood, Crag Moll., vol. i, p. 9, pl. i, fig. 11 .

Form. and Loc.-Red Crag: Butley; Hollesley. Norwich Crag: Norwich; Bramerton Common and Blake's Pit, Bramerton ; Bulchamp (S. V. Wood).

This is a common pleistocene fossil in this country, not only in the upper beds but also in the lower (Forest Bed). On the continent its earliest record is from the middle pleistocene of Cannstadt and Weimar.

\section{Paludestrina stagnalis (Bast.).}

Paludestrina ulve, Penn. : S. V. Wood, Crag Moll., vol. i, p. 109, and Suppt. I, p. 71, pl. iv, fig. 23 (as Hydrobia ulva).

Hydrobia ulva, Penn. : J. Gwyn Jeffreys, Quart. Journ. Geol. Soc., vol. xxvii (1871), p. 490.

Form. and Loc.-Red Crag: Walton (A. Bell). Norwich Crag : Norwich; Aldeby; Thorpe, near Aldeburgh ; Yarn Hill ; Bramerton Common; Beccles; and Dunwich.

The examples from Gedgrave (see Crag Moll., vol. i, p. 109) are certainly post-pliocene in age, and cannot be considered as of Coralline Crag age. The species is very abundant at Thorpe, Aldeburgh, and is by far the commonest shell of the genus in the English pliocene beds. The earliest record from elsewhere than in this country, that we have been able to trace, is from the lower pliocene (Congeria Beds) at Mauer near Vienna, and Bizenz in Moravia.

\section{Paludestrina ventrosa (Mont.).}

Paludestrina subumbilicata, Mont.: S. V. Wood, Crag Moll., vol. i, p. 108, pl. xi, fig. 2.

Hydrobia ventrosa, Mont. : J. Gwyn Jeffreys, Quart. Journ. Geol. Soc., vol. xxvii (1871), p. 490.

${ }^{1}$ A. Locard, "Variations Malac. de bassin de Rhone," vol. ii, p. 226. 
Form. and Loc.-Pliocene of St. Erth, Cornwall. Red Crag: Walton ; Butley; Felixstowe. Norwich Crag: Norwich; Bramerton Common; Blake's Pit, Bramerton.

This species is by no means a common form in the Crag. The example now in the national collection (S. V. Wood Coll.), said to come from the Coralline Crag of Sutton, is, judging by its condition, certainly not a Coralline Crag fossil, and it is noteworthy that on the tablet to which it is affixed the pliocene age of the specimen is queried in Wood's own handwriting. It is a very ancient form, occurring as it does in the lower miocene of Wiesbaden, the middle miocene of Manthelan, near Tours, and the lower pliocene (Congeria Beds) at Mauer near Vienna, Bizenz in Moravia, and elsewhere. Turbo minuta, S. Woodward, ${ }^{1}$ may be either this species or Paludestrina stagnalis.

28. Paludestrina Reevei, n.sp. Fig. II.

Hydrobia obtusa. Sandb.: S. V. Wood, Crag Moll., Suppt. I, p. 30, pl. iv, fig. 7 .

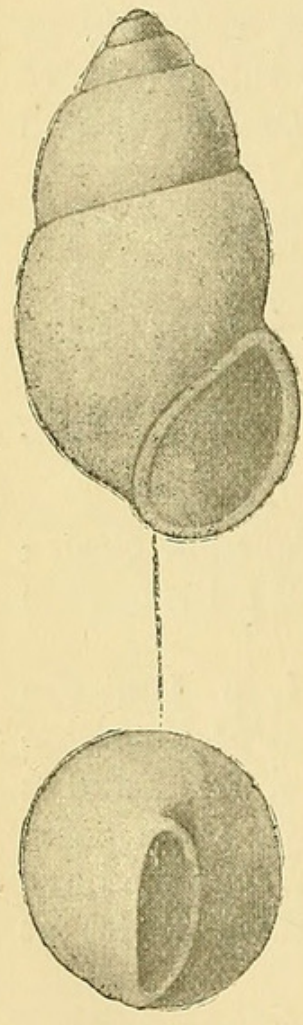

II.

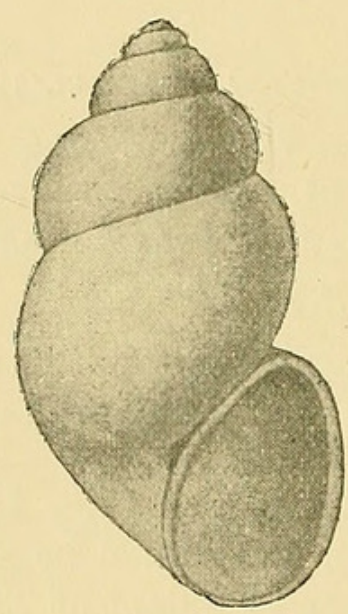

III.

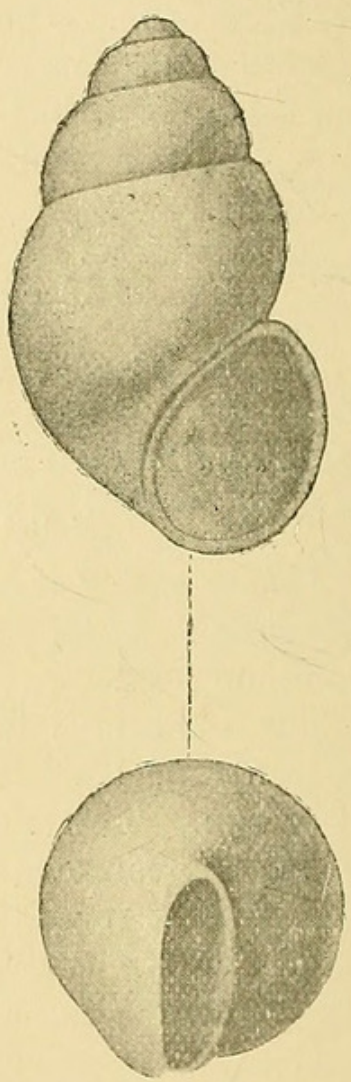

IV.

FIg. II. Paludestrina Reevei, n.sp. Norwich Crag.

,, III. obtusa, Sandb., var. Lower Miocene: Frankfort-on the-Maine.

, IV. —— type. Upper Oligocene: Kleinkarben (Wetterau).

1 S. Woodward, Outline of the Geology of Norfolk, 1833, p. 44, pl. iii, fig. 20. 
Testa parvula, ovato-conica, apice perobtuso, basi oblique rimata; anfractus 4 , leviter convexiusculi, læves, sutura impressa, ultimus vix inflatior et paulo deflexus circa $\frac{2}{3}$ partem altitudinis totius adæquans. Apertura obliqua, ovalis, superne acuminata, marginibus continuis, simplicibus, columellari subrecto, subreflexo. Operculum ignotum. Long. 2, diam. $1 \mathrm{~mm}$.

Form. and Loc.-Norwich Crag: Blake's Pit, Bramerton (Brit. Mus. and Norwich Mus.).

This, although it bears some resemblance to the figures of $P$. obtusa given by Sandberger, proves on comparison with specimens kindly sent for the purpose by Dr. Boettger to be a different shell. The latter is $3 \mathrm{~mm}$. long by about $1.25 \mathrm{~mm}$. in diameter, and its last whorl is much larger than the preceding one, whereas in the present species they are nearly equal in size. P. Reevei, too, has a far blunter spire, less convex whorls, a more oblique aperture, and no similar thickening: on the outer lip. It is by no means a common shell, only about a dozen specimens being known; all of these have been found by Mr. Reeve, after whom we have great pleasure in naming this form, since by his persistent work he has greatly extended our knowledge of the molluscan fauna of the Norwich Crag.

\section{Bythinia tentaculata (Linn.).}

Paludina tentaculata, Linn.: S. V. Wood, Crag Moll., vol. i, p. 111, pl. xii, fig. 2.

Form. and Loc.-Norwich Crag: Norwich; Bramerton Common and Blake's Pit, Bramerton (Norwich Mus.); Southwold (Brit. Mus.); Bulchamp (S. V. Wood).

This is a very rare form in the Crag, although so abundant at the present time. On the continent it is first known from the lower pliocene (Congeria Beds) of Bruchstück, and it is also recorded from the middle pliocene of Hauterive, France.

\section{Vivipara glacialis (S. V. Wood).}

Paludina glacialis, S. V. Wood : Crag Moll., Suppt. I, p. 68, pl. iv, fig. 14, and pl. vii, fig. 25 .

Form. and Loc.-Norwich Crag: Coltishall (S. V. Wood).

The only evidence of the occurrence of this form in the pliocene of England is the statement by Mr. S. V. Wood that a single example was found by Mr. H. Norton in the Norwich Crag of Coltishall. This example we have been unable to trace. There are three specimens in the Searles Wood Collection at the British Museum (Natural History), all of which are of pleistocene age, two being from Belaugh and one from Hopton. One of the Belaugh specimens is figured (Crag Moll., Suppt. I, pl. iv, fig. 14), and this should be considered the type. The example from Hopton (also figured, t.c., pl. vii, fig. 25) differs so much from the Belaugh specimens that it may even be a new form, but it is undesirable to create a new species on a single imperfectly preserved specimen. Those in the Museum of Practical Geology from the Weybourn Crag of East Runton are also of pleistocene age. 
According to Sandberger, ${ }^{2} V$. glacialis is allied to $V$. pachya, Bourg., from the Amoor. ${ }^{2}$

\section{Vivipara media (S. Woodw.).}

Paludina media, S. Woodward: Outline of the Geology of Norfolk, 1833, pl. iii, nigs. 5,6 .

Paludina rotundata, S. Woodward: op. cit., pl. iii, fig. 7 .

Paludina obsoleta?, S. Woodward: op. cit., pl. iii, fig. 4.

Paludina lenta, Brander: S. V. Wood, Crag Moll., vol. i, p. 110, pl. xii, fig. 1 .

Paludina parilis, S. V. Wood: Crag Moll., vol. ii, p. 320.

Paludina media, S. Woodw. : S. V. Wood, Crag Moll., Suppt. I, p. 69.

Paludina unicolor, Oliv: G. von Frauenfeld, Verh. k.k. Zool. Bot. Ges., 1864 , p. 153.

Paludina lenta (Brander?) : J. G. Jeffreys, Quart. Journ. Geol. Soc., vol. xxvii (1871), p. 493.

Paludina unicolor, Swainson: J. G. Jeffreys, Quart. Journ. Geol. Soc., vol. xxvi (1870), p. 282.

Paludina vivipara, Linn.: 'S. V. Wood, Crag Moll., Suppt. I, p. 70, pl. i, fig. 5 (non Linn.).

Form. and Loc.-Red Crag: Waldringfield (A. Bell). Norwich Crag: Bramerton Common; Thorpe, Norfolk; Bulchamp; Thorpe, Aldeburgh; Dunwich; Yarn Hill ; Horstead?; Postwick (S. Woodward).

Few shells in the Crag have caused more difference of opinion as to their identification than this. There can be no doubt that Paludina media and $P$. rotundata of $\mathrm{S}$. Woodward are the same species, but it is not so certain with regard to $P$. obsoleta. The figure more resembles Vivipara glacialis, but in any case it is not desirable to substitute for the well-established name media that of obsoleta, because the latter is fig. 4 and the former fig. 5. There is probably an error as to the locality of the specimen in the British Museum (Natural History) labelled "Hasleworth."

The immature example figured by Wood as Paludina vivipara, Linn., undoubtedly belongs to this species, as a careful comparison shows. With regard to the locality of this specimen, too, a mistake has probably been made. In the text it is stated that an example of Paludina vivipara was found by Mr. Cavell at Easton Bavent, but that the example figured is from the lower glacial beds at Rackheath ; whilst in the explanation of the plate the figured specimen is said to be from the Chillesford Beds, Horstead. The shell in the national collection labelled as the figured specimen is marked as coming from Horstead. Vivipara media is recorded with a query by Dr. J. Lorié ${ }^{3}$ from a boring at Gorkum, Holland, at a depth of 92 and

1 C. L. F. Sandberger, “Beitrag zur Kenntniss der unterpleistocänen Schichten Englands": Palæontographica, 1881, p. 85.

2 J. Bourguignat, "Spicileges Malacol.," p. 9, pl. vii, figs. 1, 2.

3 "Contrib. à la Géol. des Pays Bas" : Archives Musée Teyler., ser. II, vol. ii, p. 163. 
120 metres. $V$. media is considered by Sandberger to be related to $V$. laeta, Martens, from Japan. ${ }^{1}$ We cannot agree with Frauenfeld that this species is identical with $P$. unicolor, Oliv, the latter having a much more pointed apex and rounded mouth; whilst the whorls are more scalariform than in $V$. media, and slightly carinate.

\section{Valvata cristata, Müll.}

Valvata cristata, Müll. : S. V. Wood, Crag Moll., Suppt. II, p. 36, pl. iv, fig. 8.

Form. and Loc.-Norwich Crag: Bramerton Common(Norwich Mus.).

No further examples of this species have been found since it was first noticed by Wood. The lower pleistocene of Mosbach is the earliest record for this form on the continent, though it is noted from several localities of more recent age.

\section{Valvata piscinalis (Müll.).}

Valvata piscinalis, Müll. : S. V. Wood, Crag Moll., vol. i, p. 112, pl. xii, fig. 3 .

Form. and Loc.-Norwich Crag: Bramerton Common and Blake's Pit, Bramerton (Norwich and Brit. Mus.).

All the examples we have seen of this species are typical, the "var. antiqua" being unknown. It has also been found in the lower pliocene (Congeria Beds) at Moosbrunn, near Vienna, and St. Leonhards, in West Slavonia.

\section{Corbicula fluminalis (Müll.).}

Cyrena trigonula, S. V. Wood: Lyell, Mag. Nat. Hist., 1839, ser. II, vol. iii, p. 329.

Cyrena consobrina, Caill.: S. V. Wood, Crag Moll., vol. ii, p. 104, pl. xi, fig. 15.

Corbicula fluminalis, Müll. : S. V. Wood, Crag Moll., Suppt. I, p. 119.

Form and Loc.-Red Crag: Waldringfield (A. Bell). Norwich Crag: Belaugh; Aldeby; Dunwich; Yarn Hill; Thorpe, Aldeburgh ; Bulchamp; Bramerton; Postwick; Wangford (S. V. Wood).

It is indeed remarkable how enormous has been the decrease in the area of distribution of this species since pleistocene times. In this country it occurs in beds of every age from the Red Crag to the upper pleistocene. It is first noted on the continent from the upper pliocene of Bligny, near Dijon, France, and it occurs abundantly in pleistocene deposits of that country, as well as in those of Belgium, Germany, and Austria, whilst it has been met with in similar beds as far east as Omsk, in Siberia. In modern days it is confined to Asia Minor, the Euphrates, the Nile, South Africa, and Kashmir.

1 C. L. F. Sandberger, “Beitrag zur Kenntniss der unterpleistocänen Schichten Englands": Palæontographica, 1881. 


\section{Spharium corneum (Linn.).}

Cyclas cornea, Linn.: S. V. Wood, Crag Moll., vol. ii, p. 107, pl. xi, fig. 2 .

Form. and Loc.-Norwich Crag: Norwich; Bramerton Common; Thorpe, Norfolk; Bulchamp.

A very rare form in the Crag, though extremely abundant in beds of later age. Its earliest recorded appearance on the continent is in the middle pleistocene near Potsdam. It is a common fossil in the upper pleistocene of the valley of the Somme.

\section{Pisidium annicum (Müll.).}

Pisidium amnicum, Müll. : S. V. Wood, Crag Moll., vol. ii, p. 109, pl. xi, fig. 1.

Form. and Loc.-Norwich Crag: Bramerton Common; Thorpe, Norfolk; Bulchamp ; Southwold (S. V. Wood); Beccles (W. M. Crowfoot).

All the examples we have seen are small, and fall far short of the dimensions to which this form attained during pleistocene times. Alfred \& Robert Bell have recorded ${ }^{1} P$. amnicum, var. sulcatum ( = P. astartoides, Sandb.), from the "Upper Crag". ( = Red Crag of Butley and Norwich Crag), but we have been unable to confirm this. It should be noted that the examples figured by Wood are from the pleistocene of Grays. P. amnicum is recorded by Dr. J. Lorié ${ }^{2}$ from a boring at Gorkum, Holland, at depths of 92, 94.5, 103.5, $108 \cdot 5$, and 120 metres, all being of pliocene age. It is also known from the upper pliocene of Bligny, near Dijon, France.

\section{Pisidicm fontinale (Drap.).}

Form. and Loc.-Norwich Crag: Bramerton Common (Norwich Museum).

Two valves only of this species are all that we have seen, and it has hitherto been unrecorded from the English pliocene beds, whilst on the continent it has not been detected in any deposit of that age, its earliest appearance being in the lower pleistocene of Mosbach.

\section{Pisidium pusillum (Gmel.).}

Form. and Loc.-Norwich Crag: Bramerton Common (Norwich Museum).

The examples found by Mr. Reeve are the only ones known of pliocene age. It first makes its appearance on the continent in the middle pleistocene of Cannstadt.

? A. \& R. Bell, "On the English Crags" : Proc. Geol. Assoc., vol. ii (1872), p. 215.

2 "Contrib. à la Géol. des Pays Bas" : Arch. Musée Teyler., ser. II, vol. ii, p. 163. 
We have thus a total of thirty-eight species. Of these, two forms, Pyramidula Suttonensis and Clausilia pliocena, are only known from the Coralline Crag. There are six species which are recorded from the Red Crag only. Of these one, Pyramidula rysa, is extinct; four are no longer found in this country, though living on the continent, viz., Eulota fruticum, Hygromia incarnata, Helicodonta lens, and Helix lactea ; whilst one, Cochlicopa lubrica, is still a common form in this country. Of the fourteen species common to both the Red and the Norwich Crags, one only, Vivipara media, is extinct; one other, Corbicula fluminalis, is no longer British; but the remaining twelve are still resident with us, viz., Hygromia hispida, Vallonia pulchella, Helicigona arbustorum, Pupa muscorum, Succinea putris, Paludestrina stagnalis, P. ventrosa, Limnaa palustris, L. pereger, L. truncatula, Planorbis marginatus, and $P$. spirorbis. Of the sixteen species known only from the Norwich Crag two are extinct, Paludestrina Reevei and Vivipara glacialis; one, Hygromia rubiginosa, is extinct in this country, though living on the continent; the remainder are all British, viz., Sphyradium edentulum, Pupa cylindracea, Succinea elegans, S. oblonga, Bythinia tentaculata, Limnca auricularia, Planorbis corneus, Valvata cristata, $V$. piscinalis, Pisidium amnicum, P. pusillum, $P$. fontinale, and sipharium corneum.

Twelve recorded species are rejected by us, viz. :-

Planorbis vortex (Linn.), first given by Lyell (2), and afterwards by

Wood (3). This is probably an error for P. spirorbis. Ancylus lacustris, Müll.

Limnaa stagnalis (Linn.).

Planorbis albus, Müll.

Pisidium astartoides, Sandb.

(= in part $P$. amnicum, var. sulcatum).

Vivipara vivipara (Linn.).

Limnce elodes, Say.

Holböllii, Möll.

All recorded by Alfred \& Robert Bell (12), but no examples have been traced, and it should benoted that $L$. stagnalis was originally given with a query.

\section{Pingelii, Möll.}

Carychium minimum, Müll., was first cited by Prestwich, and the

For reasons stated ante, p. 196. specimen stated to be in the Norwich Museum, but it cannot be traced.

Assiminea Grayana, Leach, though listed and figured by Wood (Crag Moll., Suppt. II, p. 35, pl. iii, fig. 18), is admitted by him to be doubtful, and the specimen cannot now be traced.

Unio tumidus, Retz.: Wood states (Crag Moll., Suppt. I, p. 118) that in 1864 he found an imperfect specimen of Unio at Bramerton, which appeared to resemble $U$. tumidus. Since we have also failed to trace this specimen it is advisable to delete it from the list. The three valves of this species formerly on view in the Natural History Museum and labelled "Red Crag: Sutton" are obviously not pliocene fossils at all, as also is the case with the example of Pyramidula rotundata (Miill.) in the Robert Bell Collection labelled "Coralline? Crag: Boyton," and still retaining some of its coloration.

VOL. III.-MARCH, 1899. 


\section{TABLE OF THE DISTRIBUTION OF THE PLIOCENE NON-MARINE MOLLUSCA OF ENGLAND.}

$\times$ Occurrence in England. $\quad$ * Extra-British.

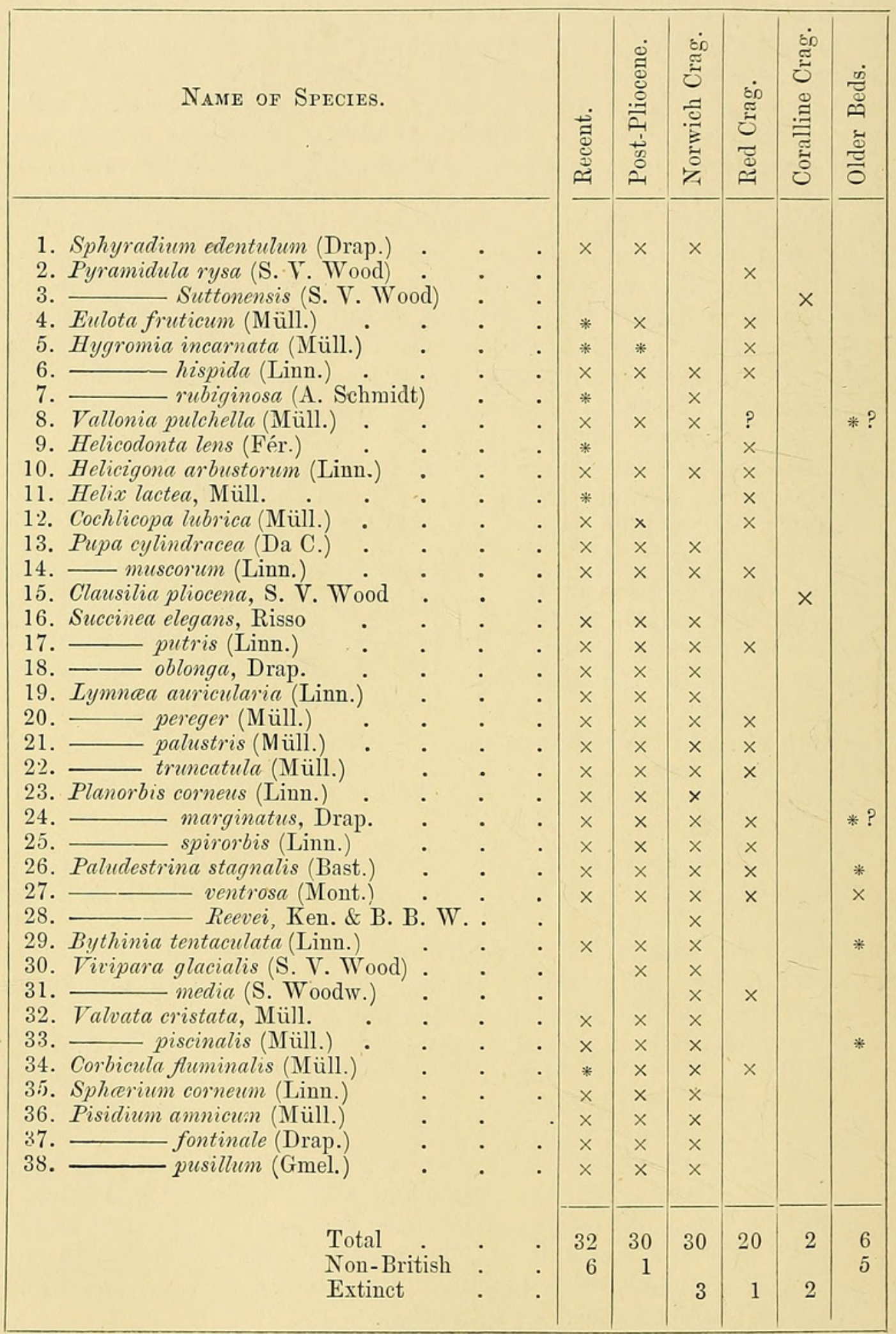




\section{$2 \mathrm{BHL}$ Biodiversity Heritage Library}

Kennard, A. S. and Woodward, Bernard Barham. 1899. "A REVISION OF THE PLIOCENE NON-MARINE MOLLUSCA OF ENGLAND." Proceedings of the Malacological Society of London 3, 187-204.

View This Item Online: https://www.biodiversitylibrary.org/item/100098

Permalink: https://www.biodiversitylibrary.org/partpdf/202692

\section{Holding Institution}

Field Museum of Natural History Library

\section{Sponsored by}

Smithsonian

\section{Copyright \& Reuse}

Copyright Status: Public domain. The BHL considers that this work is no longer under copyright protection.

This document was created from content at the Biodiversity Heritage Library, the world's largest open access digital library for biodiversity literature and archives. Visit BHL at https://www.biodiversitylibrary.org. 